\title{
DEVELOPMENTS OF THE EUROPEAN UNION'S EXPORT DIRECTIONS IN THE CONTEXT OF THE US-EU TRADE WAR
}

\author{
Jolanta Solnyškiniené ${ }^{1}$, Beata Černis ${ }^{2}$ \\ Department of Business Management, Faculty of Business Management, \\ Vilnius Gediminas Technical University, Sauletekio al. 11, LT-10221, Vilnius, Lithuania \\ E-mails: ${ }^{1}$ jolanta.solnyskiniene@gmail.com (corresponding author); ${ }^{2}$ beata.cernis@stud.vgtu.lt
}

Received 23 March 2020; accepted 06 May 2020

\begin{abstract}
The article assesses which countries in the world are most suitable for export such goods as aluminum, steel, cheese, and meat from the European Union in the context of the European Union - US trade wars. The theoretical study is designed to identify factors that promote the export and import of goods and to identify factors that can be used for further multicriteria research. An investigation using multi-criteria methods, EDAS, TOPSIS and SAW, revealed alternative export countries in the context of the EU-US trade war. The calculated RCA index showed the competitiveness of the analyzed products: aluminum, steel, cheese and meat in the selected countries. Another step was a forecast of exports of the analyzed goods and also was made conclusions to which countries are most suitable to export aluminum, steel, meat, and cheese in the context of the European Union-US trade war.
\end{abstract}

Keywords: export, EU, USA, MCDM, EDAS, TOPSIS, SAW, RCA, forecast, trade war.

JEL Classification: F13, F14, CO2, F17.

\section{Introduction}

Trade wars in the economy are not a new phenomenon. The trade wars concept is important for the economy, its origins and other aspects were analyzed by such authors as Horwell (1966), Rodriguez (1974), Kuga (1973), Bagwell and Staiger (1999), Grossman and Helpman (1995), Berthou, Jardet, Siena, and Szczerbowicz (2018), Hoekman (2020).

Conybeare (1987, p. 3) defines trade wars as "an intensive international conflict, when countries interact, negotiate and retaliate mainly for economic purposes, which are directly related to their economies by their sold goods or service sectors, which are limited by restrictions on the free flow".

Jahnson (1953) was one of the first researchers who tried to prove that trade wars can be beneficial for large countries, but small countries in trade wars most often lose than win. The same opinion also has Bouët and Laborde (2017) which emphasizes several types of trade wars. The first type is the global trade war, which brings damage to the global economy. The second type is a trade war between the two countries. In such a trade war two countries take damage, but usually, the larger country wins and the smaller country loses (Bouët \& La-borde 2017).

The trade war between China and the USA started in the middle of 2018, and a bit later the trade war moved to the European Union. The trade war between the USA and the EU was started in 2018 when the USA set 25 proc. import duty on steel and a 10 proc. import duty on aluminum. Also in 2019 , the USA increased import duties for cheese and meat that are imported to the USA from the EU.

When the USA increased import duties for goods that were imported from the EU, the EU countries suffered a loss. Breuss and Christen (2019) has created a simulation model that shows how the import duties for steel and aluminum impacted the economy. The authors state that the best international trade result is in those countries, where import duties were not applied - Canada, Mexico, South Corea, Portugal, Brazil. Also, it is seen that when the USA increase the import duties for goods that were imported from the EU, EU steel export to the USA has fallen by 64 proc., and aluminum export has fallen by 49 proc.

The authors McCarthy (2019), Breuss and Christen (2019), Kilolo (2018) state that the trade war will force affected countries to change their export directions.

It can be concluded that trade wars hurt all countries that are involved in them. Therefore, we can state that trade wars have the worst impact on smaller countries. Although it is mentioned that large countries may benefit from a trade war, however, this does not always happen. (Berthou et al., 2018) point out that annual export volumes of all 
countries involved in trade wars are decreasing; therefore the countries are forced to look for other, alternative export markets.

According to experts, the US-EU trade war is a continuation of the US-China trade war.

Liu and Woo (2018) emphasizes tree main points that encouraged the USA to start a trade war with China: 1) a huge disbalance in China - USA trades have slowed down job creations in the USA; 2) China has used illegal methods to obtain technologies from the USA; 3 ) the USA was sure that China wanted to decrease USA national safety and theirs international influence.

This paper will analyze in which countries it is most appropriate to export EU goods for which the USA has increased import duties rates in the context of the European Union - United States trade war.

The objective of this paper: to determine alternative export directions of steel, aluminum, cheese and meat of the European Union in the context of the US-EU trade war.

Work tasks:

1. Using methods of multi-criteria evaluation (MCDM) (EDAS, TOPSIS, SAW) to find out in which countries it is best for the European Union to export their products.

2. Calculate the RCA index for exported steel, aluminum, cheese and meat and to determine whether the exported products are competitive in the selected countries.

3. Produce export forecasts of the analyzed products to the sampled countries.

4. Research methods: analysis and synthesis of scientific literature, calculation of RCA index, methods of multicriteria evaluation (EDAS, TOPSIS, SAW), prognosis.

\section{Methodology for assessing export expansion opportunities in the context of US and EU trade}

To find out countries where the European Union should export their products, it is important to know what are the most important factors influencing export development processes.

In order to determine which criteria are most suitable for research, it was chosen to prepare an analysis of the scientific literature. Literature analysis was performed using 25 scientific literature articles on export expansion opportunities. After analyzing the literature, those authors who talked about criteria that are important for the export extension opportunities were chosen. After analysis, only 4 main criteria were left, because the authors emphasized the importance of these criteria the most.
After analyzing the scientific literature on the subject of export development, summarized factors influencing the change of export indicators are presented in the table below.

Table 1. Export criteria (composed by authors)

\begin{tabular}{|c|c|c|c|c|}
\hline Author & 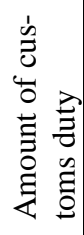 & 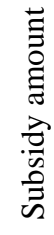 & 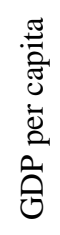 & 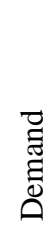 \\
\hline $\begin{array}{l}\text { Beckman, Estrades, and } \\
\text { Aguiar (2019) }\end{array}$ & + & + & + & + \\
\hline Kilolo (2018) & + & - & - & + \\
\hline McCarthy (2019) & + & - & + & - \\
\hline $\begin{array}{l}\text { Breuss and Christen } \\
(2019)\end{array}$ & + & + & + & - \\
\hline Qiu and Wei (2019) & + & + & + & + \\
\hline $\begin{array}{l}\text { Chen, Crespi, Hahn, } \\
\text { Schulz, and Taha (2019) }\end{array}$ & - & - & - & + \\
\hline $\begin{array}{l}\text { Chang, McAleer, and } \\
\text { Nguyen (2019) }\end{array}$ & - & + & - & + \\
\hline $\begin{array}{l}\text { Tolkachev and Teplyakov } \\
(2018)\end{array}$ & + & + & - & + \\
\hline $\begin{array}{l}\text { Mizuno and Takauchi } \\
(2018)\end{array}$ & + & + & - & + \\
\hline Corbo (2019) & + & - & + & + \\
\hline $\begin{array}{l}\text { Araújo, Chalaux, and } \\
\text { Haugh (2018) }\end{array}$ & - & - & + & + \\
\hline Aldcroft (2019) & + & - & + & + \\
\hline $\begin{array}{l}\text { Pervaz, Petrovic, Pecujli- } \\
\text { ja, and Cosic (2018) }\end{array}$ & + & + & - & + \\
\hline $\begin{array}{l}\text { Dergachova and Boiko } \\
\text { (2018) }\end{array}$ & + & - & + & + \\
\hline $\begin{array}{l}\text { Costinot and Rodríguez- } \\
\text { Clare (2018) }\end{array}$ & - & - & + & + \\
\hline
\end{tabular}

Note: Here + indicates that the author considers the indicator to have an impact on exports, and this indicator is important in the export valuation, - indicates that the author considers the indicator irrelevant to the export valuation, or the author has no opinion on the indicator.

In this study multi-criteria approaches (MCDM) such as the SAW, TOPSIS and EDAS will be used to find out in which countries it is best for the European Union to export their products in the context of the EU - USA trade war. These methods allow us to rank our investigation countries.

One of the most popular and easier multicriteria methods is the SAW method. The main purpose of this method is to find a value for each criterion and in this way to give a rank for all criteria. The first step in the SAW method is to create a 
normalized matrix and to calculate an $S_{j}$ indicator to set up a rank for criteria (Anggraeni et al., 2018).

$$
S_{j}=\sum_{i=1}^{m} w_{i} \bar{r}_{i j},
$$

where: $\bar{r}_{i j}-j$ alternatives $i$ criterion value.

The normalization matrix is compiled by normalizing criteria. In this step, it is established whether the criterion is minimizing or maximizing. In this way, we establish normalization matrix values (Anggraeni et al., 2018).

$$
\begin{aligned}
& \bar{r}_{i j}=\frac{\min _{j} r_{i j}}{r_{i j}} ; \\
& \bar{r}_{i j}=\frac{r_{i j}}{\max _{j} r_{i j}},
\end{aligned}
$$

where: $\bar{r}_{i j}-j$ alternatives $i$ criterion value.

One of the exceptions to the SAW method is that a criterion cannot be a negative one, it is why it is necessary to convert negative criterion to a positive criterion.

$$
\widehat{r}_{i j}=r_{i j}+\left|\min _{j} r_{i j}\right|+1 \text {. }
$$

Another multi-criteria method is a TOPSIS method. With this method, we can establish criterion rank by the ideal positive and the ideal negative criterion. According to Karim and Karmaker (2016), a positive ideal solution consists of all the good values that a criterion can achieve, whereas a negative ideal solution consists of all the worst values of a criterion. With the TOPSIS method, when the alternatives that come from all the criteria help determine the exact rank, in this way a decision matrix is formed (Karim \& Karmaker, 2016). Below is an overview of the TOPSIS solution process.

Creates a vector matrix based on 5 formula:

$$
n_{i j}=\frac{x_{i j}}{\sqrt{\sum_{i=1}^{m} x_{i j}^{2}}},
$$

where: $\bar{n}_{i j}-i$ indicator $j$ object value; $i=1, \ldots, m$; $j=1, \ldots, n$.

After performing matrix normalization, we can calculate a weighted matrix using formula 6 :

$$
v_{i j}=w_{i} n_{i j},
$$

where: $\bar{w}_{i}-j$ criterion weight.
In defining the ideal positive $V^{+}$and ideal negative $V$-solutions we use formulas 7 and 8 :

$$
V^{+}=\left(v_{1}^{+}, v_{2}^{+}, \ldots, v_{n}^{+}\right)=\left(\left(\max _{i} v_{i j} \mid j \in I\right),\left(\min _{i} v_{i j} \mid j \in J\right)\right) ;
$$

$V^{-}=\left(v_{1}^{-}, v_{2}^{-}, \ldots, v_{n}^{-}\right)=\left(\left(\min _{i} v_{i j} \mid j \in I\right),\left(\max _{i} v_{i j} \mid j \in J\right)\right)$,

where: $I$ - set of maximizing indices; $J$ - a set of minimizing indices; $[(\max )]_{-} i /[(\min )]_{-} i-$ the weight of the indicator.

As discussed above, the authors Karim and Karmaker (2016) note the importance of calculating the ideal positive and the ideal negative distance to the criteria in the TOPSIS method. We calculate the distance using formulas 9 and 10 .

$$
\begin{aligned}
& S_{i}^{+}=\sqrt{\sum_{j=1}^{n}\left(v_{i j}-v_{i}^{+}\right)^{2}} ; \\
& S_{i}^{-}=\sqrt{\sum_{j=1}^{n}\left(v_{i j}-v_{i}^{-}\right)^{2}} .
\end{aligned}
$$

By calculating the positive and negative distances, we can calculate the relative proximity to the positive ideal solution according to formula 11:

$$
P_{i}=\frac{s_{i}^{-}}{s_{i}^{-}+s_{i}^{+}} .
$$

With the Gave $P_{i}$ value, we can give each survey unit rank and determine where it ranks among all the survey units.

According to the authors Stanujkic, Zavadskas, Ghorabaee, and Turski (2017), the EDAS method is one of the most recently introduced multi-criteria methods. The basic idea behind the EDAS approach is to use two distance measures: positive distance from the mean (PDA) and a negative distance from the mean (NDA). The first step in this approach is to identify the most important criteria describing the alternatives and construct the decision matrix.

The second step is to determine the average solution for all criteria:

$$
A V_{j}=\frac{\sum_{i=1}^{n} x_{i j}}{n} .
$$

The third step is to calculate the positive distance from the mean $\left(P D A_{i j}\right)$ :

If $j$ criterion is maximizing:

$$
P D A_{i j}=\frac{\max \left(0,\left(x_{i j}-A V_{j}\right)\right)}{A V_{i}} .
$$

If $j$ criterion is minimizing: 


$$
P D A_{i j}=\frac{\max \left(0,\left(A V_{j}-x_{i j}\right)\right)}{A V_{i}} .
$$

The fourth step is to reverse the negative distance from the mean:

If $j$ criterion is maximizing:

$$
N D A_{i j}=\frac{\max \left(0,\left(A V_{j}-x_{i j}\right)\right)}{A V_{i}}
$$

If $j$ criterion is minimizing:

$$
N D A_{i j}=\frac{\max \left(0,\left(x_{i j}-A V_{j}\right)\right)}{A V_{i}} .
$$

The fifth step is to calculate the weighted $P D A_{i j}$ amount:

$$
S P_{i}=\sum_{j=1}^{m} w_{j} P D A_{i j} .
$$

The sixth step is to calculate the weighted $N D A_{i j}$ amount:

$$
S N_{i}=\sum_{i=1}^{m} w_{j} N D A_{i j} .
$$

The seventh step is to normalize the $S P_{i}$ and $S N_{i}$ values:

$$
\begin{aligned}
& N S P_{i}=\frac{S P_{i}}{\max _{i}\left(S N_{i}\right)} ; \\
& N S N_{i}=1-\frac{S P_{i}}{\max _{i}\left(S N_{i}\right)} .
\end{aligned}
$$

The eighth step is to calculate the $N S P_{i}$ and $N S N_{i}$ averages:

$$
A S_{i}=\frac{1}{2}\left(N S P_{i}+N S N_{i}\right) .
$$

The last, ninth step is to rank the criteria according to the $A S_{i}$ values obtained.

Multi-criteria evaluation by SAW TOPSIS and EDAS compares the results. The objects used in the study are potential importing countries, and the criteria by which the research is conducted show the results of potential importing countries. The study is conducted to evaluate which countries are most suitable for export from the European Union in the context of the US-EU trade war.

To determine whether the exported goods are competitive in the countries in which the EU will be able to export goods in the context of the EU US trade war it calculates the RCA index for each commodity in the countries:

$$
R C A_{A i}=\frac{\frac{x_{A j}}{\sum_{j \in P} x_{A j}}}{\frac{X_{w j}}{\sum_{j \in P} x_{w j}}} \geq 1,
$$

where: $P$ - number of products, $X_{A i}-$ country; $A-$ export of product, $X_{w i}-$ word export of product, $\sum_{i \in P} X_{A i}$ - country A export value, $\sum_{i \in P} X_{w i}-$ world export value.

\section{Study of European Union export expansion opportunities in the context of US-EU trade war}

As mentioned earlier for this study will be used such methods as EDAS, TOPSIS, and SAW. Using multi-criteria methods, the goal was to determine which countries are best for exporting products for which the US has increased customs duties, ie meat, cheese, steel, and aluminum, from the European Union. The country was satisfactory in terms of imports of a particular product into the country. The results of each study are summarized below.

\subsection{Expansion opportunities for steel exports}

In Table 2 below is shown a list of selected countries for the study, as well as the criteria for those countries that were selected from the scientific literature analysis.

Table 2. The meanings of the criteria of the selected countries for steel export study

\begin{tabular}{|l|c|c|c|c|}
\hline & Duties & $\begin{array}{c}\text { Share of } \\
\text { exports in } \\
\text { GDP }\end{array}$ & $\begin{array}{c}\text { Share of } \\
\text { imports in } \\
\text { GDP }\end{array}$ & $\begin{array}{c}\text { Share of } \\
\text { imports } \\
\text { of a } \\
\text { country's } \\
\text { product } \\
\text { in world } \\
\text { imports } \\
\text { (2018) }\end{array}$ \\
\hline China & 0 & 0.20440252 & 0.35722041 & 1 \\
\hline Turkey & 0 & 0.31027254 & 0.33441911 & 0.8 \\
\hline Korea & 0 & 0.46121593 & 0.42345277 & 0.8 \\
\hline Thailand & 0 & 0.70020964 & 0.61346363 & 0.6 \\
\hline Vietnam & 0 & 1 & 1 & 0.6 \\
\hline India & 0 & 0.20649895 & 0.25407166 & 0.6 \\
\hline Mexico & 0 & 0.41090147 & 0.44625407 & 0.6 \\
\hline Weight & 0.25 & 0.25 & 0.25 & 0.25 \\
\hline $\begin{array}{l}\text { min/max } \\
\text { criterion }\end{array}$ & $\min$ & $\max$ & $\max$ & $\max$ \\
\hline
\end{tabular}

The first analyzed multi-criteria method in this study is the SAW method. It helps to evaluate selected countries and the criteria assigned to them, 
and also in this way we can give the ranks for those countries. This rank shows us in which countries after the trade war between the US and the European Union, it makes sense to import products. The $S_{j}$ indicator was used to rank the countries. The results of the SAW study are shown in Table 3 below.

Table 3. SAW methods results

\begin{tabular}{|l|c|c|}
\hline & $S_{j}$ & Rank \\
\hline China & 0.39 & 4 \\
\hline Turkey & 0.361 & 6 \\
\hline Korea & 0.421 & 3 \\
\hline Thailand & 0.478 & 2 \\
\hline Vietnam & 0.65 & 1 \\
\hline India & 0.265 & 7 \\
\hline Mexico & 0.364 & 5 \\
\hline
\end{tabular}

In the SAW study, each country was assigned an appropriate rank. The higher the $S_{j}$ score is - the higher the rank for the country becomes. These are the ranking results of countries: In the first place is Vietnam, in the second is Thailand and Korea is ranked third. It can, therefore, be concluded that, according to the recommendations of this method, steel is best exported to these countries. To make the study more accurate, the same country will be ranked in the survey by two other methods, TOPSIS and EDAS, the results of which are presented below. The results of the TOPSIS method are summarized in Table 4 below.

Table 4. TOPSIS method results

\begin{tabular}{|l|c|c|c|c|}
\hline & $S^{+}$ & $S^{-}$ & $P_{i}$ & Rank \\
\hline China & 0.270 & 0.055 & 0.169 & 7 \\
\hline Turkey & 0.169 & 0.205 & 0.548 & 5 \\
\hline Korea & 0.140 & 0.211 & 0.601 & 3 \\
\hline Thailand & 0.100 & 0.229 & 0.696 & 2 \\
\hline Vietnam & 0.092 & 0.228 & 0.713 & 1 \\
\hline India & 0.234 & 0.076 & 0.245 & 6 \\
\hline Mexico & 0.150 & 0.208 & 0.581 & 4 \\
\hline
\end{tabular}

In the TOPSIS study, each country was assigned an appropriate rank. The higher the $P_{i}$ score is - the higher the rank for the country becomes. These are the ranking results of countries: in the first place is Vietnam, Thailand is ranked second and Korea is ranked third. Therefore it can be concluded that, according to the recommendations of the TOPSIS method, steel is best exported to these countries. The summarized results of the EDAS method are presented in Table 5 below.
Table 5. EDAS method results

\begin{tabular}{|l|c|c|c|c|c|c|}
\hline & $S P_{i}$ & $S N_{i}$ & $N S P_{i}$ & $N S N_{i}$ & $A S_{i}$ & Rank \\
\hline China & 0.1 & 0.83 & 0.18 & 0 & 0.09 & 7 \\
\hline Turkey & 0.28 & 0.16 & 0.51 & 0.80 & 0.66 & 5 \\
\hline Korea & 0.28 & 0.038 & 0.51 & 0.95 & 0.73 & 3 \\
\hline Thailand & 0.4 & 0.04 & 0.80 & 0.95 & 0.87 & 2 \\
\hline Vietnam & 0.54 & 0.11 & 1 & 0.85 & 0.92 & 1 \\
\hline India & 0 & 0.59 & 0 & 0.28 & 0.14 & 6 \\
\hline Mexico & 0.25 & 0.09 & 0.46 & 0.88 & 0.67 & 4 \\
\hline
\end{tabular}

In the EDAS study, each country was assigned an appropriate rank. The higher the ASi score is - the higher the rank for the country becomes. These are the ranking results of countries: In the first place is Vietnam, Thailand is ranked second and Korea is ranked third. It can, therefore, be concluded that, according to the recommendations of this method, steel is best exported to these countries.

The following conclusion is that in the context of US-EU trade, steel exports from the European Union are the most appropriate to countries like Vietnam, Thailand, and Korea, because the study of using multi-criteria methods such as the SAW, TOPSIS and EDAS give the same results.

\subsection{Opportunities for aluminum export expansion}

Table 6 below shows a list of selected countries for the study, as well as the criteria for those countries that were selected from the scientific literature analysis.

Table 6. Importance of criteria for countries selected for the aluminum export survey

\begin{tabular}{|l|c|c|c|c|}
\hline & Duties & $\begin{array}{c}\text { Share } \\
\text { of } \\
\text { exports } \\
\text { in GDP }\end{array}$ & $\begin{array}{c}\text { Share of } \\
\text { imports } \\
\text { in GDP }\end{array}$ & $\begin{array}{c}\text { Share of } \\
\text { imports of a } \\
\text { country's } \\
\text { product in } \\
\text { world } \\
\text { imports } \\
(2018)\end{array}$ \\
\hline Japan & 0 & 27.44 & 6.83 & 5 \\
\hline Mexico & 0 & 39.2 & 41.1 & 4 \\
\hline Korea & 0 & 44 & 39 & 4 \\
\hline China & 30 & 19.5 & 18.7 & 3 \\
\hline India & 7.5 & 19.7 & 23.4 & 3 \\
\hline Canada & 0 & 31.8 & 33.9 & 2 \\
\hline Turkey & 0 & 29.6 & 30.8 & 2 \\
\hline Weight & 0.25 & 0.25 & 0.25 & 0.25 \\
\hline $\begin{array}{l}\text { min/max } \\
\text { criterion }\end{array}$ & $\min$ & $\max$ & $\max$ & $\max$ \\
\hline
\end{tabular}


The first analyzed multi-criteria method in this study is the SAW method. It helps to evaluate selected countries and the criteria assigned to them, and also in this way we can give the ranks for those countries. This rank shows us to which countries after the trade war between the US and the European Union, it makes sense to import products. The $S_{j}$ indicator was used to rank the countries. The results of the SAW study are shown in Table 7.

In the SAW study, each country was assigned an appropriate rank. The higher the $S_{j}$ score is - the higher the rank for the country becomes. These are the ranking results of countries: in the first place it is Korea, Mexico is a second and Japan is ranked third. It can, therefore, be concluded that, according to the recommendations of this method, aluminum is best exported to these countries. To make the study more accurate, the same country will be ranked in the survey by two other methods, TOPSIS and EDAS, the results of which are presented below. The results of the TOPSIS method are summarized in Table 8 below.

Table 7. Results of the aluminum SAW method

\begin{tabular}{|l|c|c|}
\hline & $S_{j}$ & Rank \\
\hline Japan & 0.508 & 3 \\
\hline Mexico & 0.673 & 2 \\
\hline Korea & 0.687 & 1 \\
\hline China & 0.375 & 7 \\
\hline India & 0.404 & 6 \\
\hline Canada & 0.487 & 4 \\
\hline Turkey & 0.456 & 5 \\
\hline
\end{tabular}

Table 8. Results of the aluminum TOPSIS method

\begin{tabular}{|l|c|c|c|c|}
\hline & $S_{i}^{+}$ & $S_{i}^{-}$ & $P_{i}$ & Rank \\
\hline Japan & 0.090 & 0.257 & 0.740 & 3 \\
\hline Mexico & 0.031 & 0.267 & 0.896 & 2 \\
\hline Korea & 0.028 & 0.268 & 0.905 & 1 \\
\hline China & 0.269 & 0.028 & 0.095 & 7 \\
\hline India & 0.123 & 0.185 & 0.601 & 6 \\
\hline Canada & 0.093 & 0.251 & 0.730 & 4 \\
\hline Turkey & 0.098 & 0.248 & 0.716 & 5 \\
\hline
\end{tabular}

In the TOPSIS study, each country was assigned an appropriate rank. The higher the $P_{i}$ score is - the higher the rank for the country becomes. These are the ranking results of countries: In the first place it is Korea, Mexico is a second and Japan is ranked third. Therefore it can be concluded that, according to the recommendations of the TOPSIS method, aluminum is best exported to these countries. The summarized results of the EDAS method are presented in Table 9 below.

Table 9. Results of the aluminum EDAS method

\begin{tabular}{|l|c|c|c|c|c|c|}
\hline & $S P_{i}$ & $S N_{i}$ & $N S P_{i}$ & $N S N_{i}$ & $A S_{i}$ & Rank \\
\hline Japan & 0.380 & 0.128 & 0.755 & 0.905 & 0.830 & 3 \\
\hline Mexico & 0.482 & 0 & 0.956 & 1 & 0.978 & 2 \\
\hline Korea & 0.503 & 0 & 1 & 1 & 1 & 1 \\
\hline China & 0 & 1.349 & 0 & 0 & 0 & 7 \\
\hline India & 0 & 0.257 & 0 & 0.809 & 0.405 & 6 \\
\hline Canada & 0.304 & 0.097 & 0.604 & 0.927 & 0.766 & 4 \\
\hline Turkey & 0.264 & 0.102 & 0.525 & 0.923 & 0.725 & 5 \\
\hline
\end{tabular}

In the EDAS study, each country was assigned an appropriate rank. The higher the ASi score is - the higher the rank for the country becomes. These are the ranking results of countries: In the first place it is Korea, Mexico is a second and Japan is ranked third. It can, therefore, be concluded that, according to the recommendations of this method, aluminum is best exported to these countries.

The following conclusion is that in the context of US-EU trade, aluminum exports from the European Union are the most appropriate to countries like Korea, Mexico, and Japan, because the study of using multi-criteria methods such as the SAW, TOPSIS and EDAS give the same results.

\subsection{Cheese export expansion opportunities}

Table 10 below shows a list of selected countries for the study, as well as the criteria for those countries that were selected from the scientific literature analysis.

Table 10. Criteria for the examination of cheese exports

\begin{tabular}{|l|c|c|c|c|}
\hline & Duties & $\begin{array}{c}\text { Share } \\
\text { of } \\
\text { exports } \\
\text { in GDP }\end{array}$ & $\begin{array}{c}\text { Share } \\
\text { of } \\
\text { imports } \\
\text { in GDP }\end{array}$ & $\begin{array}{c}\text { Share of } \\
\text { imports of a } \\
\text { country's pro- } \\
\text { duct in world } \\
\text { imports (2018) }\end{array}$ \\
\hline Japan & 29.46 & 17.77 & 16.83 & 4 \\
\hline Russia & 15 & 30.74 & 20.8 & 3 \\
\hline Saudi Arabia & 5 & 39.7 & 26.8 & 2 \\
\hline China & 8 & 19.5 & 18.7 & 2 \\
\hline Mexico & 45 & 39.2 & 41.1 & 2 \\
\hline Korea & 15.7 & 44 & 39 & 2 \\
\hline Weight & 0.25 & 0.25 & 0.25 & 0.25 \\
\hline $\begin{array}{l}\text { min / max } \\
\text { criterion }\end{array}$ & min & max & max & max \\
\hline
\end{tabular}


The first analyzed multi-criteria method in this study is the SAW method. It helps to evaluate selected countries and the criteria assigned to them, and also in this way we can give the ranks for those countries. This rank shows us in which countries after the trade war between the US and the European Union, it makes sense to import products. The $\mathrm{Sj}$ indicator was used to rank the countries. The results of the SAW study are shown in Table 11.

In the SAW study, each country was assigned an appropriate rank. The higher the $S_{j}$ score is - the higher the rank for the country becomes. These are the ranking results of countries: In the first place is Saudi Arabia, Korea is a second and Mexico is ranked third. It can, therefore, be concluded that, according to the recommendations of this method, cheese is best exported to these countries. To make the study more accurate, the same country will be ranked in the survey by two other methods, TOPSIS and EDAS, the results of which are presented below. The results of the TOPSIS method are summarized in Table 12 below.

Table 11. Results of cheese SAW method

\begin{tabular}{|l|c|c|}
\hline & $S_{j}$ & Rank \\
\hline Japan & 0.496 & 6 \\
\hline Russia & 0.572 & 4 \\
\hline Saudi Arabia & 0.763 & 1 \\
\hline China & 0.505 & 5 \\
\hline Mexico & 0.626 & 3 \\
\hline Korea & 0.691 & 2 \\
\hline
\end{tabular}

Table 12. Cheese results of the TOPSIS method

\begin{tabular}{|l|c|c|c|c|}
\hline & $S_{i}^{+}$ & $S_{i}^{-}$ & $P_{i}$ & Rank \\
\hline Japan & 0.157 & 0.102 & 0.395 & 6 \\
\hline Russia & 0.101 & 0.179 & 0.640 & 3 \\
\hline Saudi Arabia & 0.094 & 0.174 & 0.649 & 2 \\
\hline China & 0.135 & 0.123 & 0.478 & 5 \\
\hline Mexico & 0.188 & 0.280 & 0.598 & 4 \\
\hline Korea & 0.091 & 0.298 & 0.767 & 1 \\
\hline
\end{tabular}

In the TOPSIS study, each country was assigned an appropriate rank. The higher the $P_{i}$ score is - the higher the rank for the country becomes. These are the ranking results of countries: in the first place is Saudi Arabia, Korea is a second and Mexico is ranked third. Therefore it can be concluded that, according to the recommendations of the TOPSIS method, cheese is best exported to these countries. The summarized results of the EDAS method are presented in Table 13 below.
Table 13. Results of cheese EDAS method

\begin{tabular}{|l|c|c|c|c|c|c|}
\hline & $S P_{i}$ & $S N_{i}$ & $N S P_{i}$ & $N S N_{i}$ & $A S_{i}$ & Rank \\
\hline Japan & 0.150 & 0.330 & 0.589 & 0.112 & 0.350 & 6 \\
\hline Russia & 0.110 & 0.067 & 0.430 & 0.819 & 0.624 & 3 \\
\hline $\begin{array}{l}\text { Saudi } \\
\text { Arabia }\end{array}$ & 0.248 & 0.054 & 0.975 & 0.855 & 0.915 & 2 \\
\hline China & 0.148 & 0.225 & 0.583 & 0.394 & 0.488 & 4 \\
\hline Mexico & 0.186 & 0.371 & 0.729 & 0.000 & 0.364 & 5 \\
\hline Korea & 0.255 & 0.050 & 1.000 & 0.865 & 0.933 & 1 \\
\hline
\end{tabular}

In the EDAS study, each country was assigned an appropriate rank. The higher the $A S_{i}$ score is - the higher the rank for the country becomes. These are the ranking results of countries: In the first place is Saudi Arabia, Korea is a second and Mexico is ranked third. It can, therefore, be concluded that, according to the recommendations of this method, cheese best exported to these countries.

The following conclusion is that in the context of US-EU trade, cheese exports from the European Union it is most appropriate to such countries as Saudi Arabia, Korea, and Mexico, because the study of using multi-criteria methods such as the SAW, TOPSIS and EDAS give the same results.

\subsection{Meat export expansion opportunities}

Table 14 below shows lists of the countries selected for the study, as well as the criteria for those countries selected through the literature analysis.

Table 14. Selection criteria for meat products

\begin{tabular}{|l|c|c|c|c|}
\hline & Duties & $\begin{array}{c}\text { Share of } \\
\text { exports } \\
\text { in GDP }\end{array}$ & $\begin{array}{c}\text { Share } \\
\text { of } \\
\text { imports } \\
\text { in GDP }\end{array}$ & $\begin{array}{c}\text { Share of } \\
\text { imports of a } \\
\text { country's } \\
\text { product in } \\
\text { world imports } \\
(2018)\end{array}$ \\
\hline Japan & 0 & 27.4 & 16.8 & 8 \\
\hline China & 70 & 19.5 & 18.7 & 9 \\
\hline Russia & 15 & 30.7 & 20.8 & 2 \\
\hline Mexico & 15 & 39.2 & 41.1 & 3 \\
\hline Korea & 0 & 44 & 39 & 4 \\
\hline Canada & 0 & 31.8 & 33.9 & 2 \\
\hline Weight & 0.25 & 0.25 & 0.25 & 0.25 \\
\hline $\begin{array}{l}\text { min/max } \\
\text { criterion }\end{array}$ & min & $\max$ & $\max$ & $\max$ \\
\hline
\end{tabular}

The first analyzed multi-criteria method in this study is the SAW method. It helps to evaluate selected countries and the criteria assigned to them, and also in this way we can give the ranks for those countries. This rank shows us in which coun- 
tries after the trade war between the US and the European Union, it makes sense to import products. The $S_{j}$ indicator was used to rank the countries. The results of the SAW study are shown in Table 15.

In the SAW study, each country was assigned an appropriate rank. The higher the $S_{j}$ score is - the higher the rank for the country becomes. These are the ranking results of countries: in the first place is Korea, Mexico is a second and Japan is ranked third. It can, therefore, be concluded that, according to the recommendations of this method, meat is best exported to these countries. To make the study more accurate, the same country will be ranked in the survey by two other methods, TOPSIS and EDAS, the results of which are presented below. The results of the TOPSIS method are summarized in Table 16 below.

Table 15. Results of SAW export method for meat products

\begin{tabular}{|l|c|c|}
\hline & $S_{j}$ & Rank \\
\hline Japan & 0.48 & 3 \\
\hline China & 0.475 & 4 \\
\hline Russia & 0.357 & 6 \\
\hline Mexico & 0.556 & 2 \\
\hline Korea & 0.598 & 1 \\
\hline Canada & 0.442 & 5 \\
\hline
\end{tabular}

Table 16. Results of TOPSIS survey on meat products export

\begin{tabular}{|l|c|c|c|c|}
\hline & $S_{i}^{+}$ & $S_{i}^{-}$ & $P_{i}$ & Rank \\
\hline Japan & 0.099 & 0.265 & 0.729 & 2 \\
\hline China & 0.262 & 0.131 & 0.334 & 6 \\
\hline Russia & 0.162 & 0.192 & 0.542 & 5 \\
\hline Mexico & 0.124 & 0.215 & 0.633 & 4 \\
\hline Korea & 0.094 & 0.265 & 0.738 & 1 \\
\hline Canada & 0.139 & 0.249 & 0.642 & 3 \\
\hline
\end{tabular}

In the TOPSIS study, each country was assigned an appropriate rank. The higher the $P_{i}$ score is - the higher the rank for the country becomes. These are the ranking results of countries In the first place is Korea, Mexico is a second and Japan is ranked third. Therefore it can be concluded that, according to the recommendations of the TOPSIS method, meat is best exported to these countries. The summarized results of the EDAS method are presented in Table 17.
Table 17. Results of EDAS export method for meat products

\begin{tabular}{|l|c|c|c|c|c|c|}
\hline & $S P_{i}$ & $S N_{i}$ & $N S P_{i}$ & $N S N_{i}$ & $A S_{i}$ & Rank \\
\hline Japan & 0.429 & 0.139 & 0.983 & 0.859 & 0.921 & 2 \\
\hline China & 0.232 & 0.983 & 0.532 & 0.000 & 0.266 & 6 \\
\hline Russia & 0.025 & 0.221 & 0.057 & 0.776 & 0.417 & 5 \\
\hline Mexico & 0.192 & 0.089 & 0.441 & 0.909 & 0.675 & 4 \\
\hline Korea & 0.436 & 0.036 & 1.000 & 0.964 & 0.982 & 1 \\
\hline Canada & 0.299 & 0.145 & 0.685 & 0.852 & 0.768 & 3 \\
\hline
\end{tabular}

In the EDAS study, each country was assigned an appropriate rank. The higher the $A S_{i}$ score is - the higher the rank for the country becomes. These are the ranking results of countries: In the first place is Korea, Mexico is a second and Japan is ranked third. It can, therefore, be concluded that, according to the recommendations of this method, meat best exported to these countries.

The following conclusion is that in the context of US-EU trade, meat exports from the European Union it is most appropriate to such countries as Saudi Arabia, Korea, and Mexico, because the study of using multi-criteria methods such as the SAW, TOPSIS and EDAS give the same results.

\section{Product competitiveness}

Following country rankings, the next step was to calculate the RCA index to determine product competitiveness in certain countries. The results obtained are shown in Table 18 below.

Table 18. Competitiveness of aluminum and steel

\begin{tabular}{|l|l|c|}
\hline Product & \multicolumn{1}{|c|}{ Country } & RCA \\
\hline \multirow{4}{*}{ Aliuminum } & Korea & 0.61 \\
\cline { 2 - 3 } & Mexico & 0.378 \\
\cline { 2 - 3 } & Japan & 0.332 \\
\hline \multirow{4}{*}{ Steel } & Vietnam & 0.869 \\
\cline { 2 - 3 } & Thailand & 0.283 \\
\cline { 2 - 3 } & Korea & 1.877 \\
\hline
\end{tabular}

Tables 18 and 19 show us product RCA indexes by country. The RCA index calculations showed that the aluminum RCA index is less than 1 in any of the selected countries, but Korea is the closest to 1 . Therefore, Korea will be used for further analysis of aluminum exports. According to calculations of the steel RCA index, the highest RCA index was found in Korea, in this case, it is 1.87 , which shows that steel is a competitive 


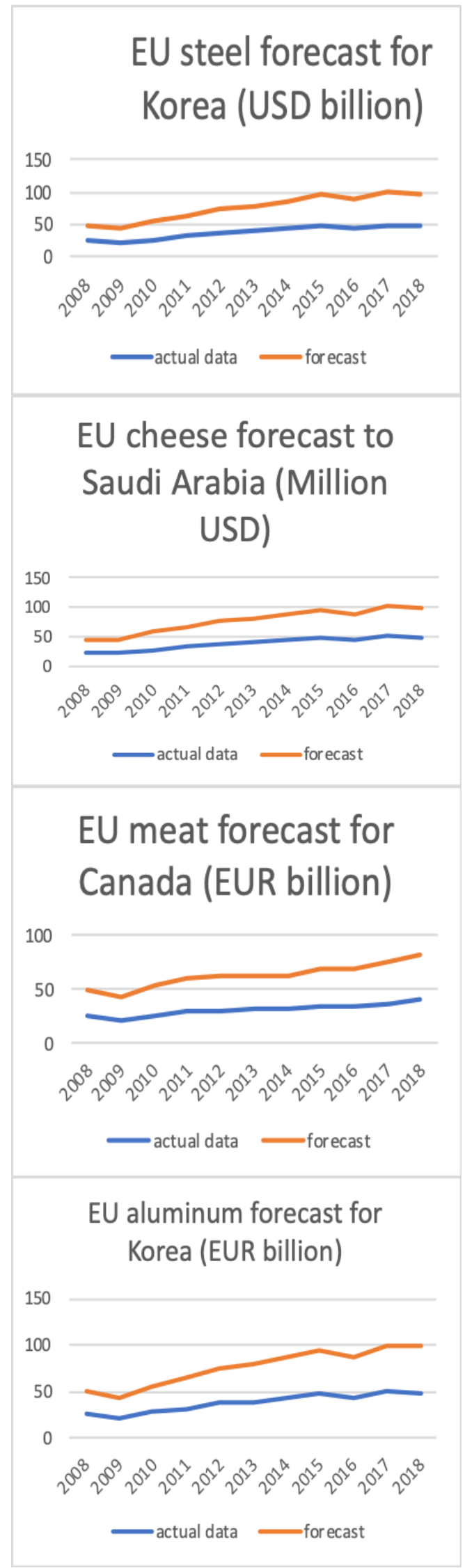

Figure 1. EU export forecast for selected goods to selected countries
Table 19. Competitiveness of cheese and meat

\begin{tabular}{|l|l|c|}
\hline \multirow{1}{*}{ Product } & \multicolumn{1}{|c|}{ Country } & RCA \\
\hline \multirow{4}{*}{ Cheese } & Korea & 0.002 \\
\cline { 2 - 3 } & Russia & 0.091 \\
\cline { 2 - 3 } & Saudi Arabia & 0.632 \\
\hline \multirow{4}{*}{ Meat } & Korea & 0.01 \\
\cline { 2 - 3 } & Japan & 0.051 \\
\cline { 2 - 3 } & Canada & 1.709 \\
\hline
\end{tabular}

product on the market in Korea, which is why Korea will be used for further investigation of steel. The cheese RCA index estimates are less than 1 in anyof the selected countries, but Saudi Arabia is closest to 1. Therefore, Saudi Arabia with an RCA index of 0.63 will be used for further analysis of aluminum exports. The RCA Meat Index estimates that Canada has the highest RCA index at 1.7, indicating that $\mathrm{m} 4 \mathrm{sa}$ is a competitive commodity in the Canadian market, which is why Canada will be chosen for further meat analysis.

With the help of the RCA index for each product was selected a country in which this product is competitive. The next step illustrates the export forecasts for the goods concerned in the context of the EU - EU trade war.

Figure 1 above shows the export forecasts of the analyzed products to the sampled countries. The graphs depict the actual export data of the European Union to the sampled countries (the actual data curve) and assume that the quantities analyzed, taking into account the EU-US trade war, will be exported to the countries sampled during the investigation (forecast curve). The predictions in Table 19 show that exports of goods subject to customs duties in the context of the EU-US trade war to the alternative countries we selected in the study will increase European exports to selected countries. Such export growth will also promote the competitiveness of goods in the markets of these countries. Therefore, such export alternatives are useful not only for the European Union but also are useful for the partner countries to which the products may be exported.

\section{Conclusions}

1. The study, using MCDM methods (SAW, TOPSIS, and EDAS), identified new directions for EU exports in the context of the EU-US Trade War. The study showed that meat products are best exported to Korea, Japan, Canada, and Mexico. Cheese products are best exported to Korea, Russia, Saudi Arabia, and Mexico and Japan. Aluminum products are best exported to Korea, Mexico, 
and Japan. And steel products are best exported to Vietnam, Thailand, and Korea.

2. According to the RCA index, aluminum and steel were found to be a competitive commodity in Korea, cheese was a competitive commodity in Saudi Arabia and meat was a competitive commodity in Canada.

3. The analysis of exports of the product concerned made by the European Union showed that exports to the alternative countries identified in the investigation, ie aluminum and steel to Korea, cheese to Saudi Arabia and meat to Canada, would increase the European Union's exports to those countries, and such an increase in exports will also promote the competitiveness of goods on the markets of those countries. Therefore, such export alternatives not only benefit the European Union but also the partner countries to which the products may be exported.

\section{References}

Aldcroft, D. H. (2019). Studies in the interwar European economy. Routledge. https://doi.org/10.4324/9780429433559

Anggraeni, E. Y., Huda, M., Maseleno, A., Safar, J., Jasmi, K. A., Mohamed, A. K., Hehsan, A., Basiron, B., Ihwani, S. S., Embong, W. H. W., Mohamad, A. M., Mohd. Noor, S. S., Fauzi, A. N., Wijaya, D. A., \& Masrur, M. (2018). Poverty level grouping using SAW method. International Journal of Engineering \& Technology, 7(2.27), 218 224. https://doi.org/10.14419/ijet.v7i2.27.11948

Araújo, S., Chalaux, T., \& Haugh, D. (2018). Who's in your export market? The changing pattern of competition in world trade (OECD Economics Department Working Papers, No. 1526). OECD Publishing. https://doi.org/10.1787/d777efc3-en

Bagwell, K., \& Staiger, R. W. (1999). An economic theory of GATT. American Economic Review, 89(1), 215-248. https://doi.org/10.1257/aer.89.1.215

Beckman, J., Estrades, C., \& Aguiar, A. (2019). Export taxes, food prices and poverty: A global CGE evaluation. Food Security, 11(1), 233-247. https://doi.org/10.1007/s12571-018-0876-2

Berthou, A., Jardet, C., Siena, D., \& Szczerbowicz, U. (2018). Costs and consequences of a trade war: A structural analysis. Rue de la Banque, (72).

Bouët, A., \& Laborde, D. (2017). US trade wars with emerging countries in the 21st Century: Make America and its partners lose again. https://papers.ssrn.com/sol3/papers.cfm?abstract_i $\mathrm{d}=3029615$
Breuss, F., \& Christen, E. (2019). Policy brief: Trump's trade wars. Implications for the EU and China. WIFO Studies.

Chang, C. L., McAleer, M., \& Nguyen, D. K. (2018). US antidumping petitions and revealed comparative advantage of shrimp-exporting countries. Reviews in Aquaculture, 11(3).

Chen, C. T., Crespi, J. M., Hahn, W., Schulz, L. L., \& Taha, F. (2019). Long-run impacts of trade shocks and export competitiveness: Evidence from the US BSE Event (CARD Working Papers. 599). https://lib.dr.iastate.edu/card_workingpapers/599

Conybeare, J. A. (1987). Trade wars: The theory and practice of international commercial rivalry (p. 183). Columbia University Press.

Corbo, V. (2019). Export-oriented development strategies: The success of five newly industrializing countries. Routledge. https://doi.org/10.4324/9780429038013

Costinot, A., \& Rodríguez-Clare, A. (2018). The US gains from trade: Valuation using the demand for foreign factor services. Journal of Economic Perspectives, 32(2), 3-24. https://doi.org/10.1257/jep.32.2.3

Dergachova, V. V., \& Boiko, O. V. (2018). Developing the export potential of domestic enterprises in terms of European integration. Ekonomichnyj visnyk NTUU ,KPI“, (15).

Grossman, G. M., \& Helpman, E. (1995). Trade wars and trade talks. Journal of Political Economy, 103(4), 675-708. https://doi.org/10.1086/261999

Hoekman, B. (2020). Trade wars and the world trade organization: Causes, consequences, and change. Asian Economic Policy Review, 15(1), 98-114. https://doi.org/10.1111/aepr.12278

Horwell, D. J. (1966). Optimum tariffs and tariff policy. The Review of Economic Studies, 33(2), 147-158. https://doi.org/10.2307/2974438

Johnson, H. G. (1953). Optimum tariffs and retaliation. Review of Economic Studies, 21(2), 142-153. https://doi.org/10.2307/2296006

Karim, R., \& Karmaker, C. L. (2016). Machine selection by AHP and TOPSIS methods. American Journal of Industrial Engineering, 4(1), 7-13.

Kilolo, J. M. M. (2018). An elementary model of export tax war. Review of World Economics, 154(2), 307325. https://doi.org/10.1007/s10290-018-0314-8

Kuga, K. (1973). Tariff retaliation and policy equilibrium. Journal of International Economics, 3(4), 351-366. https://doi.org/10.1016/0022-1996(73)90027-5

Liu, T., \& Woo, W. T. (2018). Understanding the USChina trade war. China Economic Journal, 11(3), 319-340. https://doi.org/10.1080/17538963.2018.1516256 
McCarthy, M. (2019). The market reaction to Trump's trade war (Honors Theses and Capstones, 447). https://scholars.unh.edu/honors/447

Mizuno, T., \& Takauchi, K. (2018). Optimal export policy with upstream price competition. The Manchester School, 88(2), 324-348. https://doi.org/10.1111/manc.12278

Pervaz, J., Petrovic, D., Pecujlija, M., \& Cosic, I. (2018). Improving export strategies to EU (case of Serbia). Proceedings of the 29th DAAAM International Symposium (pp. 0966-0975). https://doi.org/10.2507/29th.daaam.proceedings.139

Qiu, L. D., \& Wei, X. (2019). China-US trade: Implications on conflicts. China Economic Journal, 12(2) 175-194.

https://doi.org/10.1080/17538963.2019.1598014
Rodriguez, C. A. (1974). The non-equivalence of tariffs and quotas under retaliation. Journal of International Economics, 4(3), 295-298.

https://doi.org/10.1016/0022-1996(74)90048-8

Stanujkic, D., Zavadskas, E. K., Ghorabaee, M. K., \& Turskis, Z. (2017). An extension of the EDAS method based on the use of interval grey numbers. Studies in Informatics and Control, 26(1), 5-12. https://doi.org/10.24846/v26i1y201701

Tolkachev, S., \& Teplyakov, A. (2018). Import substitution in Russia: The need for a system-strategic approach. Problems of Economic Transition, 60(7), 545-577.

https://doi.org/10.1080/10611991.2018.1551033 